\title{
KORELASI ANTARA DISIPLIN DALAM BELAJAR DENGAN KOMPETENSI PENGETAHUAN IPS SISWA KELAS IV SD GUGUS 1 KECAMATAN MENGWI TAHUN PELAJARAN 2016/2017
}

\author{
I Gd.Ngr. Angga Diatmika, I Wy. Sujana, Made Putra \\ Program Studi Jurusan Pendidikan Guru Sekolah Dasar, Universitas Pendidikan Ganesha \\ Email : anggadiatmika2@gmail.com,sujanawyn59@gmail.com,putramd13@yahoo.com
}

\begin{abstract}
Abstrak
Penelitian ini bertujuan untuk mengetahui korelasi antara disiplin dalam belajar dengan kompetensi pengetahuan IPS siswa kelas IV SD Gugus 1 Kecamatan Mengwi tahun pelajaran 2016/2017. Jenis penelitian ini adalah penelitian ex post facto, korelasional. Populasi dari penelitian ini adalah seluruh siswa kelas IV yang ada di SD Gugus 1 Kecamatan Mengwi yang berjumlah 143 orang. Sampel ditentukan dari populasi menggunakan teknik proporsional random sampling dan jumlah sampel dari populasi ini adalah 100 orang. Data yang dikumpulkan adalah hasil dari pengisian angket tentang disiplin oleh responden, sedangkan data tentang kompetensi pengetahuan IPS didapat melalui pencatatan dokumen. Analisis statistik yang digunakan dalam penelitian ini adalah tehnik korelasi biserial. Hasil analisis data diperoleh $t_{\text {hitung }}=2,803$, sedangkan pada taraf signifikansi 5\% dan $\mathrm{dk} 98$ diperoleh nilai $\mathrm{t}_{\text {tabel }}=1,980$ sehingga $t_{\text {hitung }}=2,803>\mathrm{t}_{\text {tabel }}=1,980$. Berdasarkan kriteria pengujian maka hipotesis nol $\left(\mathrm{H}_{0}\right)$ ditolak dan hipotesis alternatif $\left(\mathrm{H}_{\mathrm{a}}\right)$ diterima. Jadi dapat disimpulkan bahwa terdapat korelasi positif yang signifikan antara disiplin dalam belajar dengan kompetensi pengetahuan IPS siswa kelas IV SD Gugus 1 Kecamatan Mengwi Tahun Pelajaran 2016/2017.
\end{abstract}

Kata kunci : disiplin dalam belajar, kompetensi pengetahuan IPS

\begin{abstract}
This study aims to determine the relationship between discipline in learning with knowledge competence of IPS fourth grade students SD Gugus 1 District Mengwi year lesson 2016/2017. This type of research is ex post facto, correlational research. The population of this study is all students of grade IV that exist in SD Gugus 1 Kecamatan Mengwi, amounting to 143 people. Samples were taken from the population using proportional random sampling technique and the sample size of this population was 100 people. The data collected is the result of the questionnaire about discipline by the respondents, while the data on IPS knowledge competence is obtained through document recording. Statistical analysis used in this research is biserial correlation technique. Result of data analysis obtained tcount $=2,803$, while at significance level ttable $=>5 \%$ and $\mathrm{dk}$ 98 obtained ttable value $=1,980$ so thitung $=2,803 \quad 1,980$. Based on the criteria of the test, the null hypothesis $(\mathrm{H} 0)$ is rejected and the alternative hypothesis $(\mathrm{Ha})$ is accepted. So it can be concluded that there is a significant positive relationship between the discipline in learning with knowledge competence IPS fourth grade students SD Gugus 1 District Mengwi Lesson 2016/2017.
\end{abstract}

Keywords: Discipline in Learning, IPS Knowledge Competence

\section{Pendahuluan}

Undang-undang Nomor 20 Tahun 2003 tentang Sistem Pendidikan Nasional sangat jelas bahwa pendidikan adalah usaha sadar dan terencana untuk mewujudkan suasana belajar dan proses pembelajaran agar peserta didik secara aktif mengembangkan potensi dirinya untuk memiliki kekuatan spiritual keagamaan, pengendalian diri, kepribadian, kecerdasan, ahlak mulia, serta keterampilan yang diperlukan dirinya, masyarakat, bangsa dan negara. Usaha menarik keluar potensi-potensi yang dimiliki peserta didik menjadi pekerjaan yang tidak ringan yang mesti dilakukan pemerintah. Usaha pemerintah tersebut tentu saja membutuhkan struktur, infrastruktur dan keterlibatan penuh seluruh elemen masyarakat tentu saja persoalan pendidikan tidak sekedar itu, masih banyak persoalan lain yang harus diselesaikan (Triwiyanto, 2014:143).

Kebutuhan akan pendidikan menjadi suatu hal yang tidak terelakan pada setiap fase sejarah peradaban manusia. Pendapat yang menyatakan bahwa pendidikan sangat dibutuhkan menjadi pendapat setiap individu dan masyarakat di setiap bangsa atau negara beradab. Melalui pemikiran dan perubahan peradaban, manusia sepakat bahwa pendidikan itu sangat penting, walaupun dengan latar belakang dan cara pandang berbeda dalam melihat keutamaannya.

Pada prinsipnya pendidikan diselenggarakan secara demokratis, terbuka, pembudayaan, dan pemberdayaan, membangun kemajuan, mengembangkan kreativitas, mengembangkan budaya membaca, menulis, berhitung bagi semua komponen pendidikan (Depdiknas,2003). Pendidikan adalah suatu usaha sadar atau kegiatan teratur dan berencana dengan maksud mengubah atau mengembangkan perilaku yang diinginkan. Pendidikan di sekolah memiliki kontribusi yang sangat besar terhadap pembentukan dan kemampuan dan pengalaman 
manusia.Sekolah atau yang sering juga disebut satuan pendidikan adalah layanan pendidikan yang menyelenggarakan pendidikan pada jalur formal, nonformal, dan informal pada setiap jenjang dan jenis pendidikan.

Dalam pendidikan formal, belajar menunjukkan adanya perubahan yang sifatnya positif sehingga pada tahap akhir akan didapat keterampilan,pengalaman, kecakapan, dan pengetahuan baru. Belajar adalah kegiatan berproses dan merupakan unsur yang sangat fundamental dalam menyelenggarakan jenis dan jenjang pendidikan, hal ini berarti keberhasilan pencapaian tujuan pendidikan sangat tergantung pada keberhasilan proses belajar siswa di sekolah dan lingkungan sekitarnya.

Belajar dipengaruhi oleh faktor-faktor intern dan ekstren pada siswa, Dimyati (2009: 246-254) menjelaskan sebagai berikut: (1) Faktor intern yang dialami dan dihayati siswa yang berpengaruh pada proses belajar yaitu sikap terhadap belajar, motivasi belajar, konsentrasi belajar, mengolah bahan ajar, menyimpan perolehan hasil belajar, menggali hasil belajar yang tersimpan, kemampuan berprestasi atau unjuk hasil belajar, rasa disiplin siswa, intelegensi dan keberhasilan belajar, kebiasaan belajar, dan cita-cita siswa. (2) Ditinjau dari segi siswa, ditemukan beberapa faktor ekstern yang berpengaruh pada aktivitas belajar yaitu guru sebagai Pembina siswa belajar, prasarana dan sarana pembelajaran, kebijakan penilaian, lingkungan sosial siswa di sekolah, dan kurikulum sekolah.

Menurut Hamalik (2012:73) Tujuan belajar adalah suatu deskripsi mengenai tingkah laku yang diharapkan tercapai oleh siswa setelah berlangsungnya proses belajar, dengan demikian tujuan belajar merupakan cara yang akurat untuk menentukan hasil pembelajaran.

Bentuk nyata yang dapat dilihat dan dirasakan dari kegiatan belajar ini adalah penguasaan kompetensi terhadap materi yang diajarkan. Kompetensi adalah sesuatu yang kompleks yang di dalamnya mengandung banyak aspek (ranah), yakni kompetensi sikap, kompetensi pengetahuan, dan kompetensi spritual (Kosasih, 2014:16).

Kompetensi dikatakan sebagai kemampuan untuk mencapai standar lulusan yang harus dimiliki siswa. Dengan demikian, maka kompetensi berkaitan dengan hasil belajar. "Hasil belajar adalah kemampuan yang diperoleh anak setelah melalui kegiatan belajar yang menyangkut aspek kognitif, afektif, dan psikomotor" (Susanto, 2013:5).

Proses penilaian terhadap kompetensi dapat memberikan informasi tentang kemajuaan peserta didik dalam upaya mencapai tujuan-tujuan belajarnya melalui kegiatan belajar atau pembelajaran terutama dalam mata pelajaran IPS selain untuk memberikan penilaian evaluasi juga sebagai alat memotivasi semangat belajar siswa, Atmaja (2016:16).Ketika guru melakukan evaluasi, siswa tentu termotivasi untuk mengerjakan soal evaluasi itu paling baik. Ketika hasil evaluasi diketahui, siswa yang mempunyai nilai tinggi akan kian termotivasi untuk menjadi yang terbaik. Sedangkan, siswa yang mempunyai nilai rendah akan terasa tertantang untuk selalu memperbaiki diri, sehingga bisa menjadi yang terbaik. Kompetensi pengetahuan IPS adalah perubahan perilaku siswa yang mencerminkan kemampuan siswa terhadap penguasaan pembelajaran IPS dari segi pengetahuan setelah mengalami proses belajar.

Fokus utama dari program IPS adalah membentuk individu-individu yang memahami kehidupan sosialnya, aktivitas dan interaksinya yang ditunjukan untuk menghasilkan anggota masyarakat yang bebas, yang mempuyai rasa tanggung jawab untuk melestarikan, melanjutkan, dan memperluas nilai-nilai dan ide-ide masyarakat bagi generasi masa depan. (Susanto, 2014:13).

Tujuan pendidikan IPS pada intinya diarahkan pada proses pengembangan potensi peserta didik agar peka terhadap masalah sosial yang terjadi di masyarakat, memiliki sikap mental positif terhadap perbaikan segala ketimpangan yang terjadi, dan terampil mengatasi setiap masalah yang terjadi sehari-hari, baik yang menimpa dirinya sendiri maupun yang menimpa masyarakat. Tujuan pembelajaran IPS di sekolah dasar bukan hanya memberikan bekal pengetahuan saja, tetapi juga memberikan bekal nilai dan sikap serta ketrampilan dalam kehidupan peserta didik di masyarakat, bangsa, dan negara dalam berbagai karakteristik.

Berhasil atau tidaknya seseorang dalam belajar disebabkan beberapa faktor yang mempengaruhi pencapaian hasil belajar yaituberasal dari dalam diri seseorang yang belajar dan ada pula dari luar diri. Pada dasarnya ada banyak faktor yang mempengaruhi hasil belajarsiswa. Menurut Rusman, (2012:124) Faktor-faktor yang mempengaruhi hasil belajar antara lain meliputi faktor internal dan faktor eksternal. Faktor internal meliputi faktor fisiologis dan faktor psikologis. Sementara faktor eksternal meliputi faktor lingkungan dan faktor instrumental.

Berdasarkan faktor-faktor yang mempengaruhi hasil belajar siswa tersebut, dapat disimpulkan bahwa secara umum ada dua faktor yang mempengaruhi hasil belajar siswa yaitu faktor internal dan faktor eksternal, yang masing-masing terdiri atas banyak faktor. Faktor-faktor tersebut saling berkaitan satu sama lain sehingga mempengaruhi keberhasilan siswa dalam belajar. Jadi agar siswa dapat memperoleh hasil belajar yang baik berbagai faktor tersebut sebisa mungkin harus disinergikan sehingga bisa mendukung proses belajar siswa.

Untuk mencapai kesuksesan dalam belajar perlu ada keyakinan diri. Dari keyakinan diri itulah kemudian timbul niat atau tekad. Dan dari tekad itulah ada usaha untuk mencapai tujuan dengan tepat. Niat memang sudah 
setengah kesuksesan suatu tindakan. Tetapi dasarnya tetap satu, yaitu disiplin (disciple).Disiplin merupakan sebuah kata yang tidak asing dalam kehidupan sehari-hari. Dalam proses belajar dan pembelajaran disiplin belajar sangat penting dalam menunjang keberhasilan siswa di kelas maupun di sekolah. Disiplin sering merujuk pada ketaatan dan kepatuhan terhadap peraturan yang berlaku.

Djamarah (2008:17) "Disiplin adalah tata tertib, yaitu ketaatan (kepatuhan) pada peraturan tata tertib dan sebagainnya. Berdisiplin berarti menaati (mematuhi) tata tertib". Seorang siswa yang memliki disiplin belajar yang baik akan mempunyai kecakapan mengenai cara belajar. Hal ini sangat diperlukan guna tercapainya hasil belajar, sebab berhasil tidaknya siswa dalam usahanya pada dasarnya tergantung pada bagaimana siswa melakukan caracara belajar yang baik.

Disiplin merupakan kunci sukses, setiap pekerjan yang dilakukan dengan penuh kedisiplinan pasti akan mengantar pada keberasilan. oleh karena itu, kedisiplinan harus ditanamkan sejak dini. Menanamkan kedisiplinan bukan hal yang mudah berbagai cara yang baik harus dilakukan. Disiplin berarti taat pada peraturan yang berlaku (tata tertib sekolah, norma masyarakat, peraturan pemerintah, dan ajaran agama). Intinya seorang yang disiplin ialah seorang yang berusaha untuk melaksanakan tugas sebaik-baiknya.orang yang disiplin tidak mudah meninggalkan kewajibannya, kecuali ada alasan yang kuat (Mustari, 2011:42). Untuk membentuk siswa yang disiplin perlu bantuan pendidikan di sekolah, di rumah, dan di masyarakat maka terbentuk manusia sebagai mahluk sosial yang seutuhnya. Namun apabila salah satu dari ketiga pendidikan tersebut tidak mendukung, maka proses sosialisasi anak akan terhambat, proses belajar juga terhambat dan berpengaruh pula pada terhambatnya hasil belajar siswa.

Dengan demikian, salah satu yang menunjang hasil belajar, terutama hasil belajar IPS siswa adalah disiplin dalam belajar. Siswa yang memiliki disiplin dalam belajar tidak akan ketinggalan dalam materi pembelajaran dan menguasai materi pembelajaran. Selain itu, siswa yang memiliki disiplin yang cenderung tinggi akan mengkondisikan dirinya bertingkah laku sesuai aturan dalam menempuh kegiatan pembelajaran. Sedangkan anak yang memiliki disiplin yang cenderung rendah tidak akan dapat mencapai tujuan pembelajaran secara optimal, karena tidak mengikuti perintah guru dengan baik.

Dari uraian sebelumnya penelitian ini dilakukan untuk mengetahui apakah disiplin dalam belajar berkorelasi secara signifikan dengan kompetensi pengetahuan IPS, penelitian tersebut dilakukan dengan judul "Korelasi Antara Disiplin dalam Belajar dengan Kompetensi Pengetahuan IPS Siswa Kelas IV SD Gugus 1 Kecamatan Mengwi Tahun Pelajaran 2016/2017”.

Tujuan yang ingin dicapai dalam penelitian ini adalah untuk mengetahui korelasi yang signifikan antara disiplin dalam belajar deng ankompetensi pengetahuan IPS pada siswa kelas IV SD Gugus 1 Kecamatan Mengwi Tahun Pelajaran 2016/2017. Penelitian ini diharapakan dapat memberikan kontribusi yang positif terhadap ilmu pendidikan, khususnya pendidikan guru sekolah dasar sehingga dapat memperluas pengetahuan tentang strategi atau pendekatan dalam proses pembelajaran untuk meningkatkan kompetensi pengetahuan siswa.

\section{Metode Penelitian}

Penelitian ini dilaksanakan pada semester 2 di kelas IV SD Gugus 1 Kecamatan Mengwi. Pemilihan SD Gugus 1 Kecamatan Mengwi sebagai tempat penelitian karena keterjangkauan dan kelayakan. Keterjangkauan dalam arti tempat penelitian mudah dijangkau oleh peneliti, serta kelayakan dalam arti di SD Gugus 1 Kecamatan Mengwi belum pernah dilakukan penelitian yang sama dengan penelitian ini. Gugus 1 Mengwi terdiri dari SDN 1 Pererenan, SDN 2 Pererenan, SDN 1Cemagi, SDN 2 Cemagi, SDN 3Cemagi, SDN 4 Cemagi.Penelitian ini dilaksanakan mulai bulan Januari sampai bulan Mei 2017.

Penelitian ini pada dasarnya bertujuan untuk mengetahui korelasi antara disiplin dengan kompetensi pengetahuan IPS, dengan tidak memanipulasi variabel bebas atau menggali fakta yang sudah terjadi sebelumnya sehingga penelitian ini tergolong penelitian ex post facto. Menurut Kerlinger (dalam Emzir 2007:119), ex post facto adalah penyelidikan empiris sistematis yang tidak mengendalikan variabel bebas secara langsung karena perwujudan variabel tersebut telah terjadi, atau karena variabel tersebut pada dasarnya memang tidak diberikan perlakuan. Dantes (2012:61) mengemukakan bahwa penelitian ex post facto adalah penelitian dengan mengambil kelompok-kelompok yang berbeda dan peneliti berusaha menentukan perbedaan-perbedaan ini. Ex post facto mulai dengan deskripsi situasi sekarang, yang diasumsikan sebagai akibat dari faktor-faktor sebelumnya telah ada dan memengaruhi peneliti berusaha meneliti kebelakang untuk menentukan faktor yang diasumsikan sebagai penyebab, yang mulai beroprasi pada masa yang lalu. Agar kita dapat menyimpulkan korelasi semacam sebab-akibat antar variabel tersebut, harus dapat dikumpulkan fakta (baik logika teori atau data empirik).

Jadi penelitian ex post facto adalah penyelidikan empiris sistematis yang tidak mengendalikan variabel bebas secara langsung karena perwujudan variabel tersebut telah terjadi dengan mengambil kelompok-kelompok yang berbeda dan peneliti berusaha menentukan perbedaan-perbedaan ini untuk menentukan faktor yang diasumsikan sebagai penyebab, yang mulai beroprasi pada masa yang lalu 
Dalam sebuah penelitian, pemilihan populasi merupakan hal yang sangat diperlukan. Populasi merupakan salah satu dari subjek penelitian. Populasi adalah wilayah generalisasi yang terdiri atas, objek/subjek yang mempunyai kualitas dan karakteristik tertentu yang telah ditetapkan untuk dipelajari dan kemudian ditarik kesimpulannya (Sugiyono, 2012:18). Populasi adalah keseluruhan subjek penelitian (Suharsimi, 2010:130).

Jadi berdasarkan kutipan diatas dapat disimpulkan populasi adalah keseluruhan objek/subjek penelitian yang mempunyai kualitas dan karakteristik yang telah ditetapkan untuk dipelajari dan kemudian ditarik kesimpulannya. Populasi dalam penelitian ini adalah semua siswa kelas IV SD Gugus 1 Kecamatan Mengwi tahun pelajaran 2016/2017 yang terdiri dari 6 sekolahyaitu SDN 1 Cemagi, SDN 2 Cemagi, SDN 3 Cemagi, SDN 4 Cemagi, SDN 1 Pererenan dan SDN 2 Pererenan dan 143 siswa.

Dalam melaksanakan penelitian, selain menentukan populasi, penentuan sampel merupakan hal yang sangat penting untuk mewakili populasi sebagai objek penelitian. "Sampel adalah sebagian atau wakil populasi yang diteliti (Suharsimi, 2010:131). Sedangkan Sugiyono (2012:80) mengemukakan bahwa sampel adalah bagian dari jumlah dan karakteristik yang dimiliki oleh populasi tersebut.

Jadi dapat disimpulkan sampel adalah sebagian atau wakil dari jumlah dan karakteristik populasi yang diteliti.Dalam melakukan penelitian banyak sekali teknik sampel yang ada, namun untuk penelitian ini, teknik yang digunakan dalam mengambil sampel adalah teknik proporsional random sampling.

Menurut Netra (1974:14) teknik sampling proporsional digunakan apabila cara pengambilan sampel memperhitungkan adanya proporsi atau besar kecilnya perbandingan antara bagian- bagian yang ada dalam suatu populasi. Prosedur yang ditempuh dilakukan dengan jalan mengambil individu yang terdapat dalam masing masing kategori populasi, sesuai dengan proporsi atau perimbangan untuk dijadikan sampel penelitian, sedangkan menurut Sugiyono (2012:82) teknik proporsional sampel digunakan bila populasi memiliki anggota atau unsur yang tidak homogen dan berstrata secara porporsional. Proporsional sampel merupakan jumlah sampel yang diambil dari strata yang sebanding, sesuai dengan proporsional ukurannya. Random adalah pengambilan anggota sampel dari populasi dilakukan secara acak. Jadi teknik proporsional random sampling adalah teknik pengambilan sampel secara acak dengan memperhatikan jumlah siswa dari masing-masing kelas. Dalam penentuan jumlah sampel dapat dilihat pada tabel Issac and Michel dalam tabel tersebut dijelaskan tentang besarnya sampel yang diambil dari populasi dengan tingkat kesalahan 1\%, 5\%, dan 10\%. Sesuai dengan tabel tersebut, jumlah populasi di Gugus 1 Kecamatan Mengwi sebanyak 131 orang, sedangkan populasi yang ada dalam tabel Issac and Michel yang mendekati jumlah populasi di Gugus 1 Kecamtan Mengwi adalah 143 orang, jadi jumlah sampel yang diambil dengan tingkat kesalahan 5\% adalah 100 orang.

Data yang dikumpulkan dalam penelitian ini adalah data disiplin dan kompetensi pengetahuan IPS siswa kelas IV SD Gugus 1 Kecamatan Mengwi tahun pelajaran 2016/2017. Metode pengumpulan data yang di gunakan dalam penenelitian ini adalah dengan metode kuesioner/angket dan pencatatan dokumen. Kegiatan pengumpulan data dilaksanakan pada siswa yang menjadi sampel di kelas IV SD Gugus 1 Kecamatan Mengwi tahun pelajaran 2016/2017. Pada penelitian ini pengumpulan data terhadap disiplin siswa dalam belajar di kumpulkan dengan metode nontes yaitu dengan memberikan angket disiplin. Sedangkan data kompetensi IPS siswa didapat dengan metode pencatatan dokumen kompetensi pengetahuan IPS semester 1 melalui nilai ulangan akhir semester tahun pelajaran 2016/2017.

Untuk menentukan layak tidaknya suatu instrumen maka perlu divalidasi. Dalam penelitian ini untuk menguji kevalidan butir angket peneliti menggunakan validitas logis. Menurut Suharsimi, (2015: 80), ada dua macam validitas logis yaitu validitas isi, untuk menguji ketepatan suatu istrumen ditinjau dari segi materi yang diujikan (untuk tes) atau ditinjau dari segi dimensi dan indikator yang ditanyakan (untuk angket) dan validitas konstruk, untuk menguji validitas konstruk instrumen penelitian non tes, setelah instrumen dikonstruksi tentang aspek-aspek yang akan diukur berlandaskan teori tertentu selanjutnya dikonsultasikan kepada ahli materi (judgement experts).

Dalam uji hipotesis penelitian ini menggunakan korelasi "beserial". Korelasi beserial digunakan jika data yang di dapat berupa data ordinal dan data interval. Uji statistik nonparametrik didasarkan pada data nominal dan ordinal dan sampel besar dimana asumsi-asumsi parametrik tidak dicapai (Styosari,2010:254). Berdasarkan hal tersebut, dalam penelitian ini data yang dikumpulkan bersifat ordinal serta sampel yang dipakai merupakan sampel besar maka uji statistik yang digunakan adalah korelasi biserial.

Pengetesan nilai koefisien korelasi beserial dilakukan secara tidak langsung. Maksudnya bahwa faktor yang di uji itu bukanlah koefisien korelasi beserial, tetapi faktor lain. Adapun faktor lain yang di uji disini adalah nilai " $t$ " yang di peroleh dari rumus transformasi. Dengan rumus ini, maka nilai koefisien korelasi beserial di transformasikan kedalam nilai " $t$ " signifikan tidaknya nilai " $t$ " berlaku sepenuhnya terhadap nilai koefisien korelasi beserial. Jadi apabila di dalam pengujian nilai " $t$ ” adalah signifikan, maka ini berati nilai koefisien korelasi beserial adalah juga signifikan. Demikian juga sebaliknya. Pengujian arah koprelasi juga dilakukan untuk mengetahui arah korelasi negatif atau positif. 
Kriterianya jika harga $t_{\text {hitung }}$ lebih kecil dari harga $t_{\text {tabel}}$, maka Ho diterima dan Ha ditolak, dan jika harga $\mathrm{t}_{\text {hitung }}$ lebih besar dari harga $\mathrm{t}_{\text {tabel }}$ maka Ho ditolak dan Ha diterima. Pada taraf signifikansi $5 \%(\mathrm{t}=1,980)$ atau taraf kepercayaan $95 \%$ dan $\mathrm{dk}=\mathrm{n}-2$.

\section{Hasil dan Pembahasan}

Berdasarkan hasil analisis data diketahui bahwa rerata kompetensi pengetahuan IPS $\bar{X}=78.73$, Mo $=77.192, \mathrm{Me}=77.928, \mathrm{Xt}=91, \mathrm{Xr}=70$ Data kompetensi pengetahuan IPS siswa juga disajikan dalam grafik berikut.

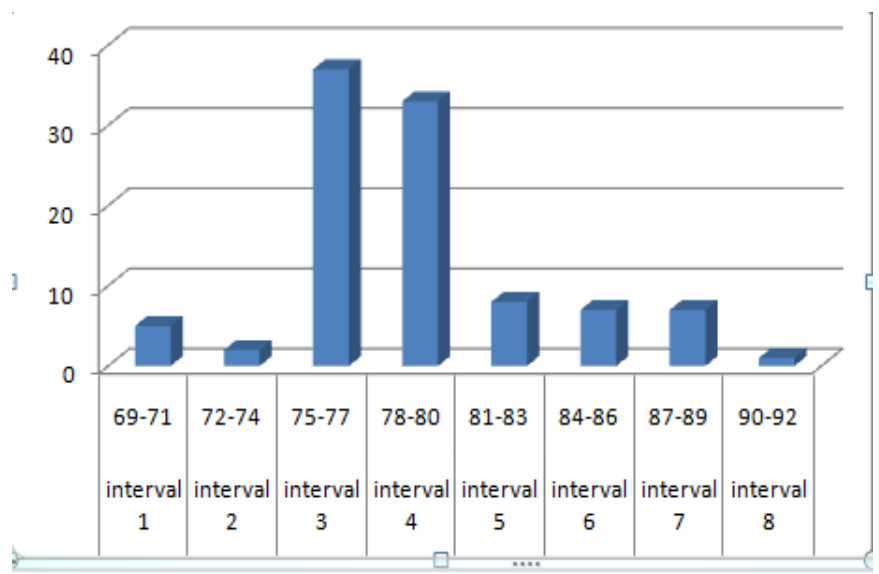

Analisis skor disiplin siswa diketahui bahwa $\bar{X}=82.87$, Mo $=84.605, \mathrm{Me}=83.833, \mathrm{Xt}=97, \mathrm{Xr}=43$. Data disiplin siswa juga disajikan dalam grafik berikut.

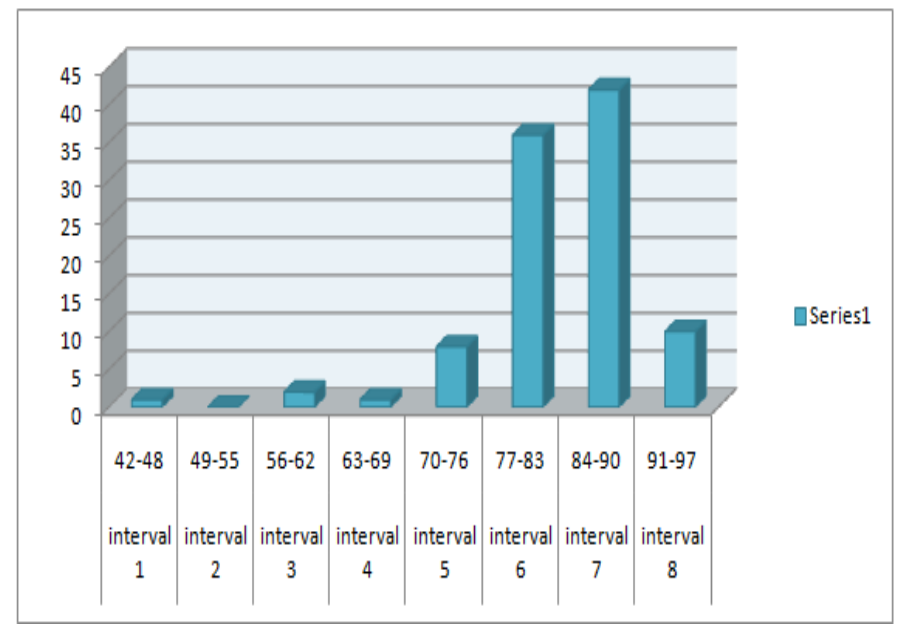

Berdasarkan jenis data yang dikumpulkan dapat diketahui bahwa data yang diperoleh dari rasa disiplin siswa dalam belajar yaitu bersifat ordinal sedangkan data kompetensi pengetahuan IPS siswa bersivat interval maka uji statistik yang dipakai adalah uji nonparametrik yaitu korelasi biseria yang ditansformasikan kedalam bentuk nilai t.

Adapun kriteria pengujiannya adalah apabila $t_{\text {hitung }}<\mathrm{t}_{\text {tabel}}$, maka Ho diterima (gagal ditolak) dan Ha ditolak. Sebaliknya apabila $t_{\text {hitung }}>t_{\text {tabel}}$, maka Ho ditolak dan Ha diterima.

Dengan $\mathrm{db}=\mathrm{n}-2$ dan taraf signifikansi $5 \%(\mathrm{t}=1,980)$ atau taraf kepercayaan $95 \%$. Hasil uji transformasi nilai t dapat dilihat pada tabel 1 .

Tabel 1. Tabel Hasil Analisis Uji transformasi nilai t

\begin{tabular}{llllll}
\hline $\mathrm{N}$ & $\mathrm{Dk}$ & $\mathrm{SD}_{\text {tot }}$ & $\mathrm{r}_{\text {bis }}$ & $t_{\text {hitung }}$ & $t_{\text {tabel }}$ \\
\hline
\end{tabular}


100

Untuk mengetahui signifikansi hasil perhitungan uji hipotesis di atas, maka perlu dibandingkan dengan nilai $t_{\text {tabel. }}$. Harga $t_{\text {tabel }}$ dengan taraf signifikansi $5 \%$ dan $\mathrm{dk}=93(\mathrm{n}-2)=1,980$. Hasil analisis uji $\mathrm{t}$ diperoleh $t_{\text {hitung }}=$ 2,803 . Harga tersebut kemudian dibandingkan dengan harga $t_{\text {tabel }}$ dengan $\mathrm{dk}=100-2=98$ dan taraf signifikansi $5 \%$ diperoleh harga $t_{\text {tabel }}=1,980$, karena $t_{\text {hitung }}=2,803>\mathrm{t}_{\text {tabel }}=1,980$ maka $\mathrm{H}_{\mathrm{o}}$ yang menyatakan tidak terdapat korelasi positif yang signifikan antara disiplin dalam belajar dengan kompetensi pengetahuan IPS siswa yang dibelajarkan melalui pembelajaran kelas IV SD Gugus 1 Kecamatan Mengwi tahun pelajaran 2016/2017 ditolak atau $\mathrm{H}_{\mathrm{a}}$ diterima.

Sebagai implikasi dari hasil penelitian ini adalah bahwa guru harus banyak memberikan rangsangan untuk meningkatkan disiplin siswa dalam belajar terutama dalam mata pelajaran IPS. Guru adalah fasilitator dalam kegiatan pembelajaran, guru juga bertugas sebagai motivator, yang memotivasi siswanya. Dengan memotivasi siswanya, tentu akan berdampak positif. Salah satu cara memotivasi adalah dengan memberi pujian atas keberhasilan yang diperoleh siswa, sehingga siswa akan semakin berminat untuk belajar lebih.

Disiplin tidak akan tumbuh secara langsung melainkan melalui suatu proses yang positif. Proses yang positif tersebut didapatkan dalam kehidupan di lingkungan keluarga, sekolah dan masyarakat. Adapun sekolah merupakan salah satu proses yang positif untuk menumbuhkan rasa disiplin siswa. Karena guru akan menanamkan keyakinan dalam diri siswa untuk meningkatkan kemampuan siswa baik dari sikap, pengetahuan dan keterampilan. Dengan demikian rasa disiplin terbentuk dan berkembang melalui proses belajar di dalam interaksi seseorang dengan lingkungannya.

Penelitian ini diperkuat oleh penelitian ini diperkuat oleh yulia citra (2016) yang menyimpulkan bahwa bahwa terdapat koreasi yang signfikan antara disiplin belajar dengan prestasi belajar IPS siswa kelas IV SD Negeri 1 Rajabasa Kota Bandar Lampung Tahun Pelajaran 2015/2016. thitung = 0,746 > tabel =0,294 dan Rose Andriyani Saputri yang menyimpulkan bahwa ada hubungan yang positif Disiplin Belajar Terhadap Prestasi Belajar Pendidikan Kewarganegaraan Pada Siswa Kelas IV SD Negeri Gugus Cakra Kecamatan Ngaliyan Kota Semarang 2016/2017 dengan hasil uji signifikansi nilai koefisien korelasi didapatkan nilai $t_{\text {hitung }} 0,370$. Nilai $t_{\text {tabel }}$ dengan $n=79$ adalah sebesar 0,219. Hal ini menunjukkan bahwa $r_{\text {hitung }} 0,370>r_{\text {tabel }} 0,219$.

\section{Simpulan dan Saran}

Berdasarkan hasil analisis diperoleh $t_{\text {hitung }}=2,803$ dengan $t_{\text {tabel }}=1,980$ yang berarti $t_{\text {hitung }}>t_{\text {tabel }}$, sehingga dapat disimpulkan terdapat korelasi yang positif signifikan antara disiplin dalam belajardengan kompetensi pengetahuan IPS siswa kelas IV SD Gugus 1 Kecamatan Mengwi tahun pelajaran 2016/2017. Apa bila berdasarkan uraian tersebut kita mengemukakan interpretasi, maka ini berarti bahwa rata-rata murid-murid yang tergolong memiliki disiplin tinggi dapat memperoleh nilai IPS yang lebih tinggi dari pada murid-murid yang memiliki disiplin rendah. Berdasarkan hasil penelitian ini, maka dapat diajukan beberapa saran guna peningkatan kualitas pembelajaran yaitu kepada guru Berdasarkan temuan penelitian yang diperoleh, disarankan kepada guru agar lebih menumbuhkan rasa disiplin siswa dalam belajar sehingga tujuan pembelajaran tercapai secara optimal

Kepada kepala sekolah agar dapat menggunakan hasil penelitian ini sebagai pendukung sumber belajar guru dalam meningkatkan kualitas pembelajaran dengan menumbuhkan disiplin siswa dalam belajar di sekolah sehingga sekolah mampu menghasilkan siswa yang berkualitas. Serta kepada peneliti lain agar hasil penelitian ini digunakan sebagai referensi untuk melaksanakan penelitian selanjutnya dan semoga penelitian ini bermanfaat bagi seluruh elemen masyarakat yang menggunakan penelitian ini.

\section{Daftar Pustaka}

Agung, A.A.Gede. 2016. Statistika Dasar untuk Pendidikan. Sin: Yogyakarta: Depublish Arikunto, Suharsini. 2010.Prosedur Penelitian Suatu Pendekatan Praktik. Jakarta: PT. Rineka Cipta. Atmaja, Nanda Pramana. 2016.Evaluasi Belajar-Mengajar. Yogyakarta: DIVA Pres.

Citra, Yulia. 2016. Hubungan Disiplin Belajar Dengan PrestasiIPS Siswa. Bandar Lampung: Universitas Lampung.

Dantes, Nyoman. 2012. Metode Penelitian. Yogyakarta: Andi.

Darmadi, Hamid. 2011. Metode Penelitian Pendidikan. Bandung: Alfabeta.

Depdiknas. 2003. Kurikulum 2004 Standar Kompetensi untuk Kelas IV Sekolah Dasar. Jakarta: Depdiknas.

Emzir. 2010. Metodologi Penelitian Pendidikan.Jakarta: PT Raja Grafindo Persada.

Gapi, Bernadus. 2016. "Membangun Kedisiplin Siswa melalui Kegiatan Ekstrakurikuler”. UNESE, (hlm. 432).

Hadi, Sutrisno. 2001. Statistik. Yogjakarta: Andi. 
Komalasari, Kokom. 2010. Pembelajaran Kontekstual Konsep dan Aplikasi. Bandung: PT. Refika Aditama.

Komara, Indra B. 2016. "Hubungan antara Kepercayaan Diri dengan Prestasi Belajar dan Perencanaan Karir Siswa". Psikopedagogia, Volume 55, Nomer 1 (hlm 36).

Kosasih. 2014. Strategi Belajar Dan Pembelajaran. Bandung:Yrama Widya.

Mustari,Mohamad. 2011. Nilai Karakter Refleksi untuk Penidikan Karakter. Yogyakarta: LaksBang Presindo.

Nainggolan, Togiaratua. 2011. "Hubungan Antara Kepercayan Diri dengan Kecemasan Sosial pada Pengguna Napza". Sosiokonsepsia, Volume 16, Nomer 02 (hlm 166 ).

Nazir. 2011. Metode Penelitian. Bogor: Ghalia Indonesia.

Netra, I.B.1974. Statistik Inferensial. Surabaya: Usaha Nasional

Pratiwi, Ni Luh Putu Novi. 2015. Pengaruh Pendekatan Saintifik Berbasisis Asesmen Portofolio Terhadap Hasil Belajar Pengetahuan IPS dengan Kovariabel Iklim Keluarga Siswa Kelas IV SD Gugus Ir. Soekarno Kecamatan Denpasar Selatan .Singaraja: Undiksha.

Safitri, Dini Anugrah. 2015. Hubungan Rasa Disiplin dengan Prestasi Belajar Matematika Siswa Kelas IV SDN Keramat Jati 19 Pagi. Jakarta: Universitas Islam Negeri Syarif Hidayatullah.

Sanjaya, Wina. 2009. Penelitian Tindakan Kelas. Jakarta: Kencana.

Sardiman, A.M. 2011. Interaksi \& Motivasi Belajar Mengajar. Jakarta: Rajawali Pers.

Setyosari, Punaji. 2013. Metode Penelitian Pendidikan dan Pengembangan. Jakarta: Kencana.

Sugiyono. 2012. Metode Penelitian Kuantitatif, Kualitatif Dan R\&D. Bandung: Alfabea

Suparno, 2015.Pendidikan Anak Berkebutuhan Khusus. Jakarta: Direktorat Jendral Pendidikan Tinggi

Susanto, Ahmad. 2013. Teori Belajar dan Pembelajaran di Sekolah Dasar. Jakarta: Kencana Prenada Media Group.

. 2014. Pengembangan pembelajaran IPS di Sekolah Dasar. Jakarta: Kencana Prenada Media Group.

Triwiyanto,Teguh. 2014. Pengantar Pendidikan. Jakarta: Bumi Aksara

Winataputra,Udin S. dkk. 2007. Teori Belajar dan Pembelajaran.Jakarta: Universitas Terbuka.

Yusuf,Muri. A. 2015. Asesmen dan Evaluasi Pendidikan.Jakarta: Prenamedi group. 